\title{
Concrete walls with and without openings supported on three sides
}

\author{
J.H. Doh, Y.C. Loo \\ Griffith School of Engineering, Griffith University, Gold Coast, Australia \\ S. Fragomeni \\ School of Engineering and Science, Victoria University, Melbourne, Australia
}

\begin{abstract}
The Australian Concrete Standard (AS3600-2009) includes updated guidelines for the simplified design of axially loaded walls. More specifically effective length factors have been introduced to distinguish between walls supported on two, three and four sides. There is very limited information on the behaviour of walls supported on three sides. As such this paper presents results from an experimental study on six half-scale reinforced concrete walls supported on three sides with various opening configurations. All panels, with a slenderness ratio of 30 , were subjected to a uniformly distributed axial load at an eccentricity of $t_{w} / 6$. Crack pattern behaviour and effects on ultimate strengths are discussed. Comparisons are made with identically sized wall panels supported on two, three or four sides (with and without openings) from other studies.
\end{abstract}

\section{INTRODUCTION}

The recently released Australian Concrete Standard, AS3600-2009, contains extensively revised design guidelines for concrete with compressive strengths in the range of 20 to $100 \mathrm{MPa}$. As part of this revision the scope of the simplified wall design equation has been increased to include effective length factors for walls with various support conditions, in addition to its applicability for higher concrete strengths.

The previous AS3600-2001 and current American concrete code (ACI318-2008) wall design equations are intended for load bearing walls supported at top and bottom only. Those code provisions do not directly include the effects of side restraints on the load carrying capacity. The recently released AS3600-2009 code guidelines for simplified wall design allow for increased capacity due to side restraints. More specifically, the code recognises wall panels in two-way action, supported laterally on three and four sides. However, the updated code method is still restricted to walls with slenderness ratios of less than 30 and does not account for openings such as doors or windows.

Figure 1, illustrates the hypothetical deflection and cracking characteristics at failure of axially loaded walls with the three types of support conditions. Many researchers have investigated the behaviour of reinforced concrete walls either in one-way action as in Figure 1(a), or two-way action with four sides supported as in Figure 1(b). However, only limited studies have been undertaken on walls supported on three sides as in Figure 1(c).
For solid walls in one-way action, Seddon (1956) contributed to the development of the British Standard (BS8110-1997) formula which is similar to the AS3600-2001 equation. Also the work of Fragomeni (1995) and Doh (2002) focused on improving the AS3600 equation to include the adopted effective length factors, and broadening its scope to include walls with higher slenderness ratios and higher concrete strengths. On the other hand, Oberlender (1973), Pillai and Parthasarathy (1977), Kripanarayanan (1977), Zielinski et al. (1982,1983) and Saheb and Desayi (1989) have made significant contributions to the development and refinement of the ACI 318 equation. Fragomeni and Mendis (1999) provided a detailed review of these ACI code related methods.

At various times, studies on solid two-way action walls supported on four sides were conducted by Swartz et al. (1974), Saheb and Desayi (1990), and Fragomeni (1995). These studies focused on normal strength concrete panels with low slenderness ratios (i.e. $\mathrm{H} / \mathrm{t}_{\mathrm{w}}<30$ ). Sanajayan and Maheswaran (1999) focused on slender high strength concrete (HSC) walls with side supports, and most recently Doh (2002) undertook an extensive study on two-way walls made of HSC and slenderness ratios between 25 and 40. His work provided an alternative to the AS3600-2001 equation that better represented walls beyond the scope of the code equation.

Saheb (1985) was one of the first researchers to carry out a number of tests on walls with openings in both one and two-way action. However, the slenderness ratio $\left(\mathrm{H} / \mathrm{t}_{\mathrm{w}}\right)$ of the panels tested was 12 . A re- 
cent study was conducted on twelve slender walls with various openings by Doh \& Fragomeni (2006). Particular emphasis was given to walls with slenderness ratios between 30 and 40, behaving in one-way (top and bottom supported) and two way action (four sides support). Lee (2008) continued from this work with a comprehensive experimental study that included two-way walls with openings (four sides supported). These two studies focused on improving the AS3600 design method to allow for walls with openings with varying opening configurations.

Doh et al. (2008) conducted laboratory testing on seven walls in two-way action, supported on three sides with a small opening symmetrical about the horizontal axis. To supplement these tests, the authors have recently undertaken further testing on six two-way action walls supported on three sides but with variable opening configurations. These new tests along with the work of Doh et al. (2008) will be presented in this paper. Crack pattern behaviour and ultimate strengths are discussed and compared. Also comparisons are made with identical walls previously tested by the authors in one-way (top and bottom supported) and two-way action (with four sides supported).

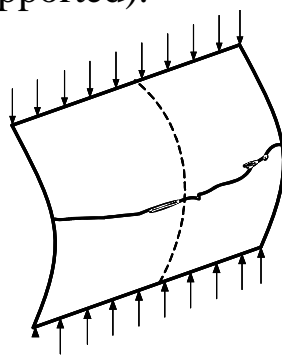

(a) One-way action (OW) (b) Two-way action (four side supports) (TW4)

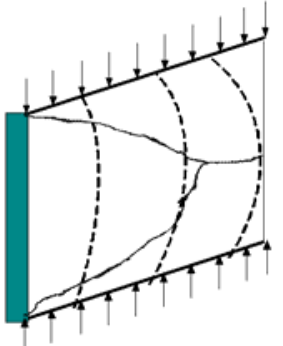

(c) Two-way action (three side supports) (TW3)
Figure 1. Behaviour of vertically loaded wall panels

\section{EXPERIMENTAL PROGRAM}

In an attempt to undertake a comparison study with the previous published research for walls behaving in one-way and two-way action, six half-scaled wall panels supported on three sides with various opening locations were casted and tested to failure.

The dimensions of the test panels (and those conducted by Doh et al (2008)) including opening locations are given in Figure 2. All walls are $1200 \mathrm{~mm}$ high x $1200 \mathrm{~mm}$ in length x $40 \mathrm{~mm}$ thick (constant slenderness ratio, $\mathrm{H}_{\mathrm{w}} / \mathrm{t}$ of 30 ). The concrete strengths and opening size dimensions are also given in Table 1. The symbols TS indicate two-way buckling with three sides supported. The third symbol denotes normal strength or high strength concrete follow by the fourth symbols of $\mathbf{C}, \mathbf{R}, \mathbf{L}, \mathbf{B}$ and $\mathbf{0}$ indicating the opening location at centre, right, left, bottom side and no opening, respectively. The last 3 digits, if given, indicate the height of openings where applicable.

For consistency, the test procedures, as described in previously published papers by Doh and Fragomeni (2005, 2006), and Doh et al. (2006, 2008) were employed. All walls were cast with minimum central reinforcement and were axially loaded at an eccentricity of $t_{w} / 6$. The walls were loaded in $20 \mathrm{kN}$ increments up to failure. At each load increment, crack patterns and deflections were also recorded.
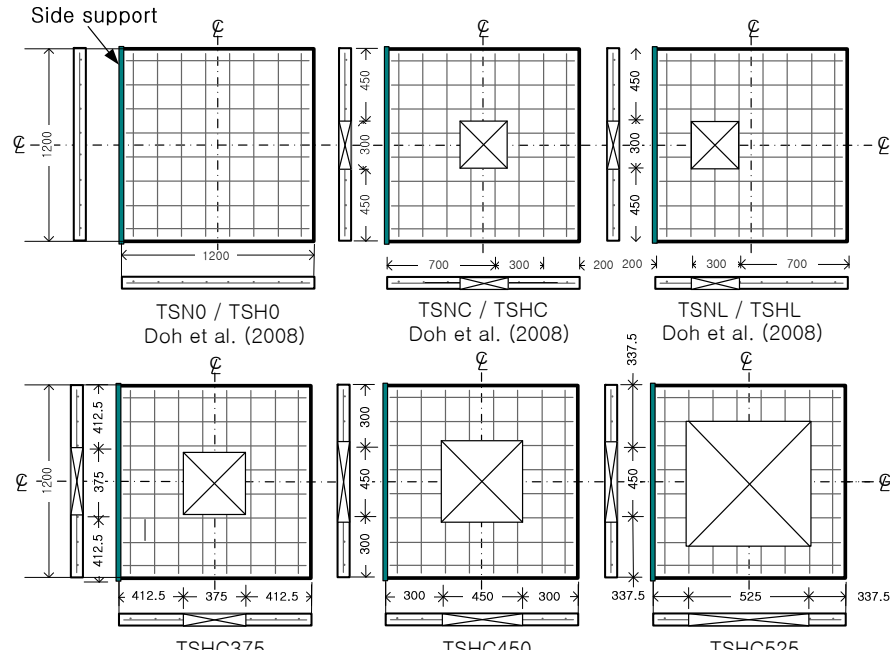

\&
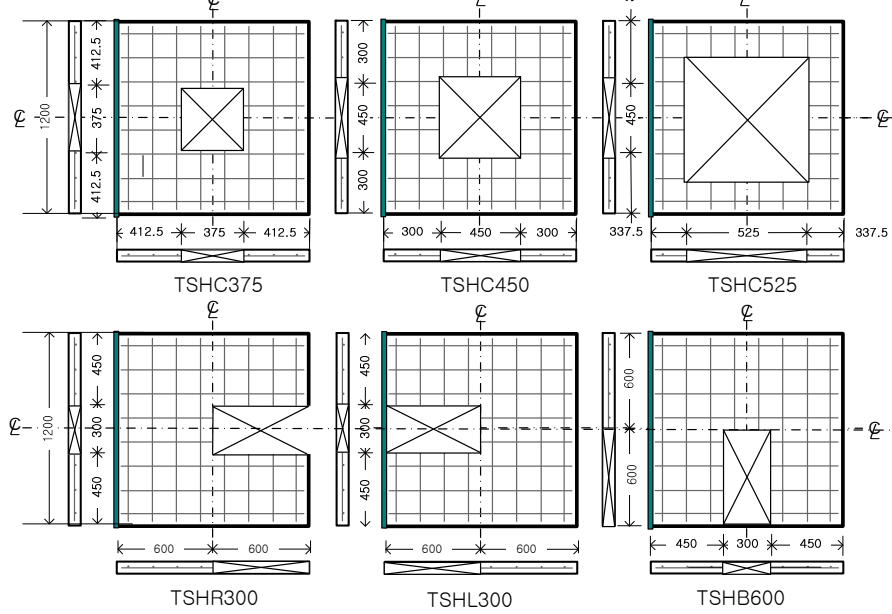

Figure 2. Panel dimensions and opening configurations (mm)

Table 1. Panel dimension and opening configuration

\begin{tabular}{|c|c|c|c|}
\hline & Model & $\begin{array}{l}\text { concrete } \\
\text { strength } \\
\mathrm{f}_{\mathrm{c}}^{\prime} \text { (MPa) }\end{array}$ & $\begin{array}{l}\text { Opening size } \\
(\mathbf{m m} \times \mathbf{m m})\end{array}$ \\
\hline \multirow{7}{*}{$\begin{array}{l}\text { Doh et al. } \\
\text { (2008) }\end{array}$} & TSNO & 50.1 & No opening \\
\hline & TSHO & 80.4 & No opening \\
\hline & TSNC & 50.1 & $300 \times 300$ \\
\hline & TSNR & 50.1 & $300 \times 300$ \\
\hline & TSNL & 50.1 & $300 \times 300$ \\
\hline & TSHC & 80.4 & $300 \times 300$ \\
\hline & TSHL & 80.4 & $300 \times 300$ \\
\hline \multirow{6}{*}{ Current } & TSHC375 & 78.5 & $375 \times 375$ \\
\hline & TSHC450 & 78.5 & $450 \times 450$ \\
\hline & TSHC525 & 78.5 & $525 \times 525$ \\
\hline & TSHR300 & 78.5 & $300 \times 600$ \\
\hline & TSHL300 & 78.5 & $300 \times 600$ \\
\hline & TSHB600 & 78.5 & $600 \times 300$ \\
\hline
\end{tabular}




\section{RESULTS AND DISCUSSION}

\subsection{Crack patterns}

Crack patterns for the panels tested are given in Figures 3 to 8 . All of the panels tested exhibited crack patterns and failure modes that are consistent with the expected behaviour of wall panels supported on three sides. That is, biaxial curvature is evident as idealised in Figure 1(c). It is evident that the majority of cracking propagated diagonally from the restrained corners to the opening and then horizontally from the opening to unrestrained edges. This unique cracking mode indicates typical two-way behaviour close to the restrained ends and one-way behaviour between unsupported edges. Also highlighted in Figure 9 are similar crack patterns experienced in the tests conducted by Doh et al. (2008).

An important crack pattern comparison can be made here between the identical normal strength and high strength concrete walls supported on three sides. The high strength concrete panels designated by TSH typically developed a single large crack, commencing at restrained corners at the tension face then horizontally towards the unrestrained edge. This indicates a brittle failure mode, with possibly some yielding of reinforcement taking place. In contrast, the normal strength panels designated by TSN exhibited more ductile behaviour with a number of parallel cracks evident as in Figures 9(b), (c) and (e).

The loaded wall panel TSHB600 with door type opening (see Figure 8) produced an asymmetric diagonal crack pattern. This can be contrasted with the one-way and two-way walls with door openings tested by Lee et al (2006) and shown in Figure 10. Interestingly the crack pattern in Figure 10(b) is very similar to that in Figure 8, except on the right side of the opening the effect of the right restraint is evident with horizontal cracks replaced by diagonal cracks.

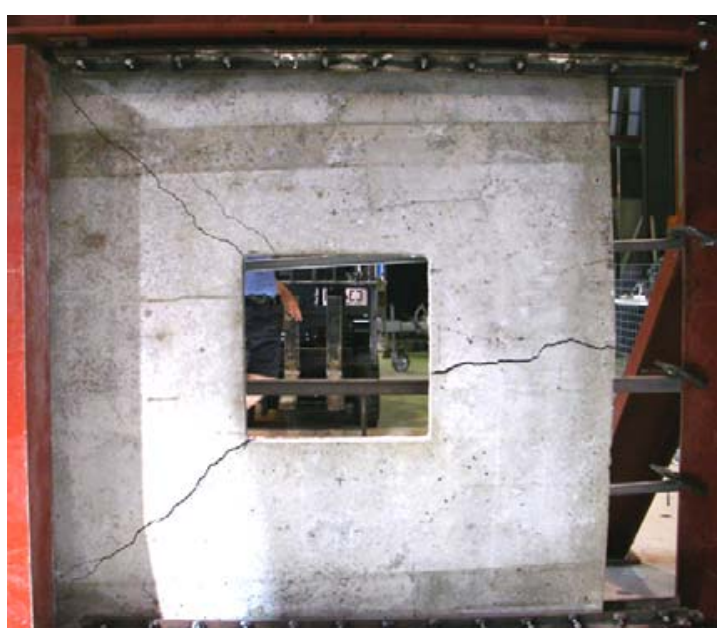

Figure 3. Failure crack patterns TSHC375

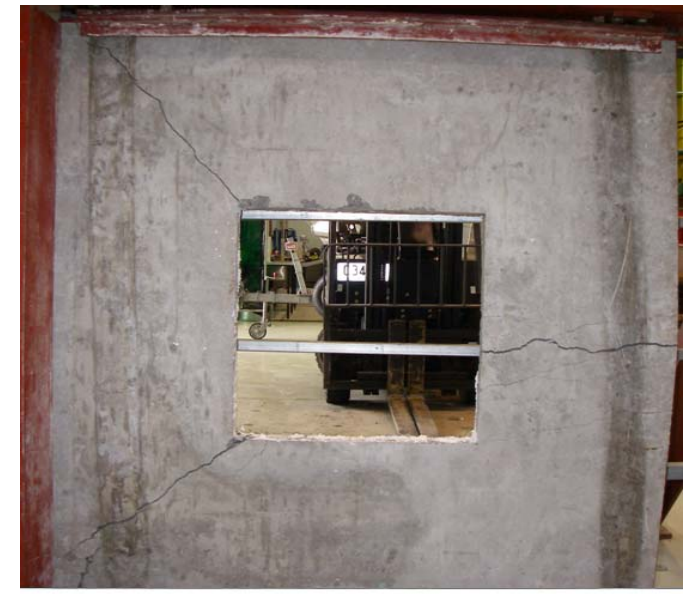

Figure 4. Failure crack patterns TSHC450

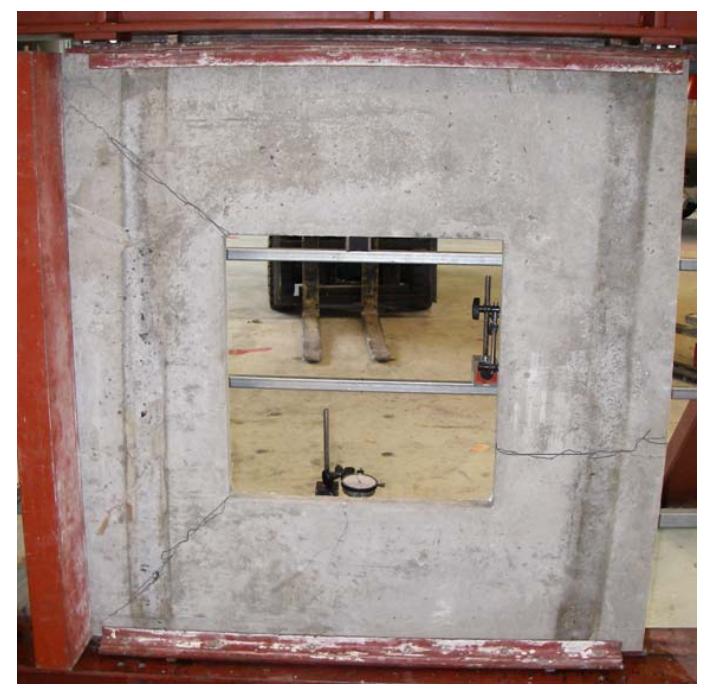

Figure 5. Failure crack patterns TSHC525

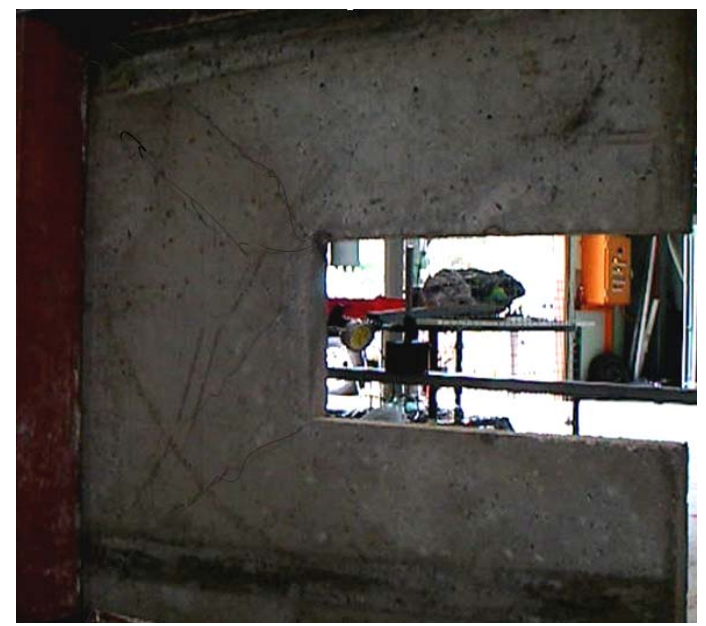

Figure 6. Failure crack patterns TSHR300 


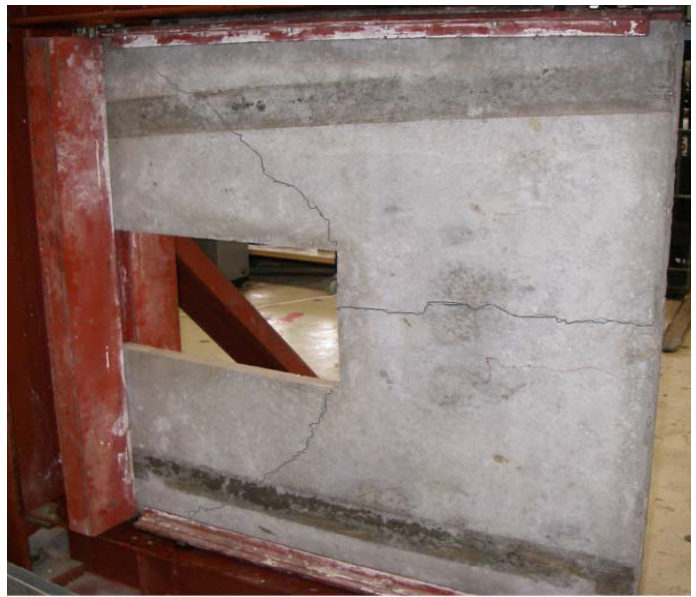

Figure 7. Failure crack patterns TSHL300

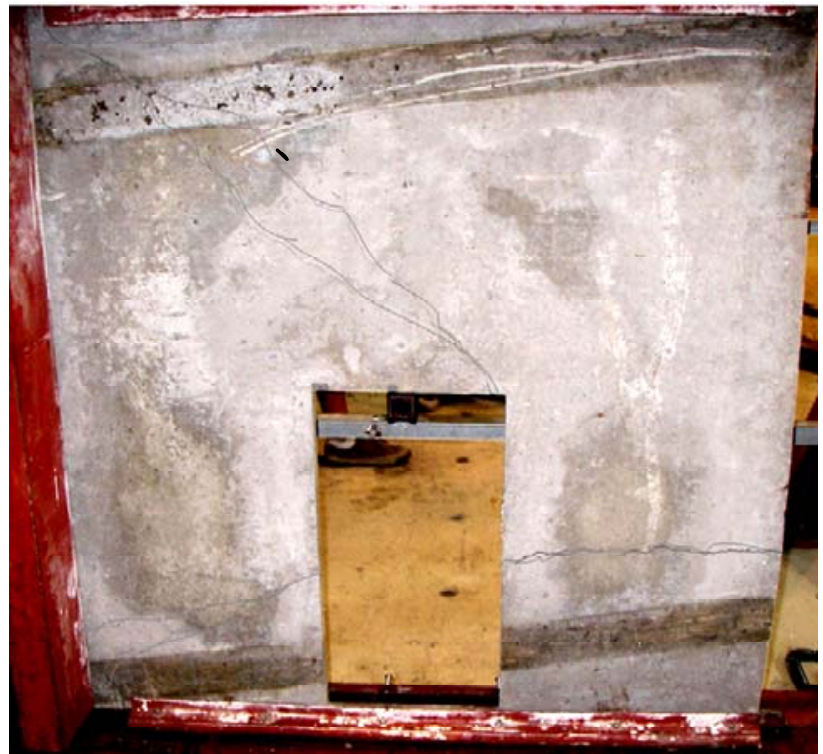

Figure 8. Failure crack patterns TSHB600

\subsection{Ultimate strength}

Table 2 provides the test panel ultimate strengths, axial strength ratios $\left(\mathrm{Nu} / \mathrm{f}^{\prime}{ }_{\mathrm{c}} \mathrm{Lt}{ }_{\mathrm{w}}\right)$ and compressive strengths, from this study and from identically sized test panels from previous research. The panel support type is identified as either OW for one-way, TW3 for two-way three sides supported, and TW4 two-way four sides supported. All panels highlighted have identical dimensions of 1200 x 1200 x $40 \mathrm{~mm}$ (slenderness ratio of 30) with variations in opening size and locations as indicated. The panel designations for the current tests and those of Doh et al. (2008) were defined in section 2. The opening size is also $300 \times 300 \mathrm{~mm}$ for test panels by Doh et al. (2006) and Lee et al (2006), placed symmetrically about the horizontal axis and to the left, centre or right as indicated. The panels by Doh and Fragomeni (2005) are without openings.

It can also be observed from Table 2 that varying the one opening location left, centre or right about the central horizontal axis on TW3 walls has an ef- fect on axial strength. As seen from Figure 13, the axial strength ratio of panels with one opening near the side restraint tends to be smaller than if the opening was near the free side. This suggests that the opening creates one-way action behaviour if it is closer to the side restraint negating its additional load effect. Figure 14 further shows the combined effect of one opening on the left side and additional side supports. Adding side supports increases the load capacity of walls irrespective of small opening location, as was found for Figures 11 and 12.

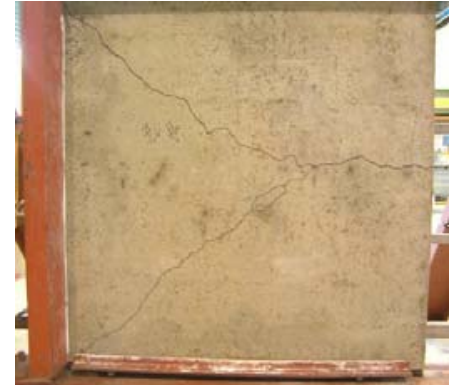

a) TSH0 tension face

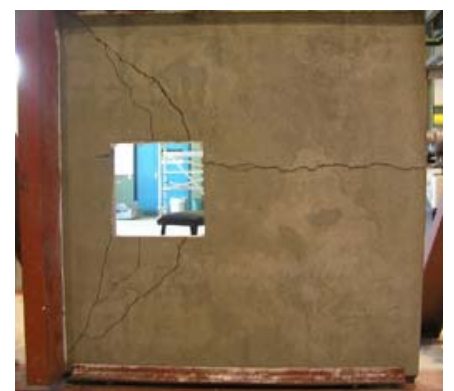

c) TSNL tension face

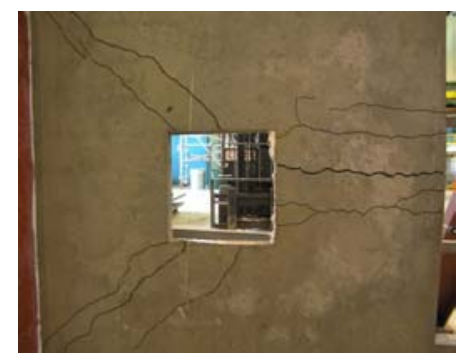

e) TSNC tension face

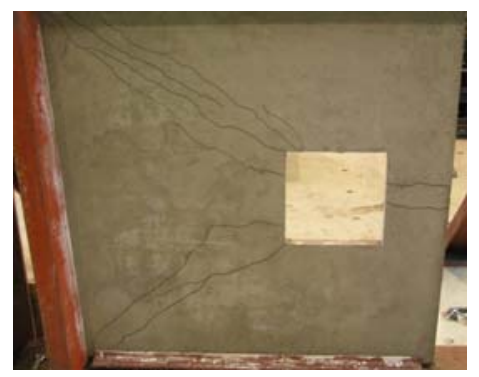

b) TSNR tension face

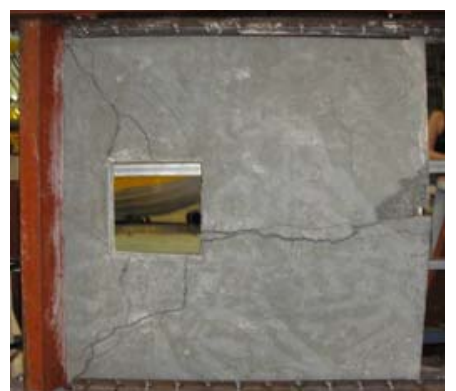

d) TSHL tension face

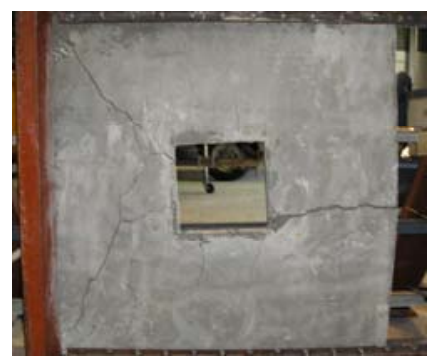

f) TSHC tension face
Figure 9. Crack patterns of walls with three sides restraints (Doh et al. (2008))

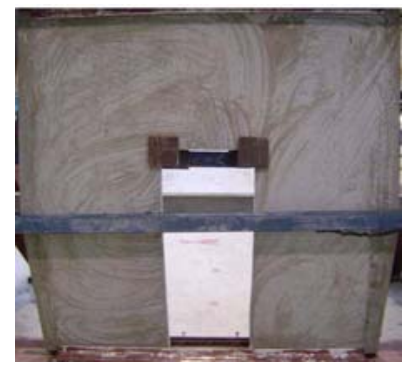

a) O65D1C1.2 (One-way)

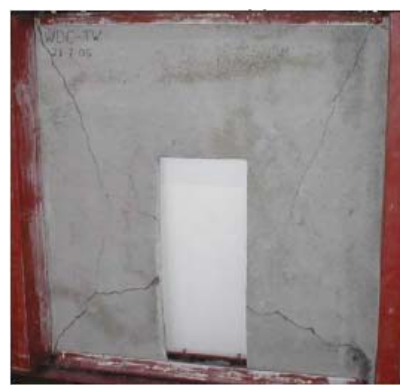

b) T65D1C1.2 (Two-way)
Figure 10. Failure crack pattern of walls with door openings (Lee, et al. (2006)) 
The trends of the current tests on TW3 walls are highlighted in Figure 15, where increasing opening size from $300 \times 300 \mathrm{~mm}$ to 525 × $525 \mathrm{~mm}$ causes an obvious decrease in axial load capacity, as expected. Further Table 2 shows that for the walls TSHR300 and TSHL300, that have large off-centre openings, relatively low axial strengths were recorded. This indicates that designers need to ensure that large openings are avoided as the perceived advantages gain from having side restraints may not be worthwhile.

From the comparative study, it is evident that varying the location of opening and support condition in wall panels can have a substantial effect on the ultimate load capacity, as did altering the restraint.

Table 2 Ultimate loads, concrete strength and axial strength ratio of wall panels

\begin{tabular}{|c|c|c|c|c|c|}
\hline port & $\begin{array}{l}\text { p- } \\
\text { type }\end{array}$ & $\begin{array}{l}\text { Panel } \\
\text { Designation }\end{array}$ & $\begin{array}{l}f_{\text {'c }}^{\prime} \\
\text { (MPa) }\end{array}$ & $\begin{array}{l}\mathbf{N}_{\mathrm{u}} \\
(\mathbf{k N})\end{array}$ & $\frac{\mathrm{N}_{\mathrm{u}}}{\mathrm{f}_{\mathrm{c}}{ }^{\mathrm{L}} \mathrm{Lt}_{\mathrm{w}}}$ \\
\hline \multirow{4}{*}{$\begin{array}{l}\text { Doh \& } \\
\text { Frago- } \\
\text { meni } \\
\text { (2005) }\end{array}$} & \multirow{2}{*}{ OW } & OWNS1 & 35.7 & 253.1 & 0.148 \\
\hline & & OWHS1 & 78.2 & 482.7 & 0.129 \\
\hline & \multirow{2}{*}{ TW4 } & TWNS1 & 37.0 & 735.8 & 0.414 \\
\hline & & TWHS1 & 64.8 & 1177.2 & 0.378 \\
\hline \multirow{2}{*}{$\begin{array}{l}\text { Doh et } \\
\text { al. } \\
\text { (2006) }\end{array}$} & OW & $\begin{array}{l}\text { WWL-OW } \\
\text { (opening left) }\end{array}$ & 64.5 & 258.4 & 0.083 \\
\hline & TW4 & $\begin{array}{l}\text { WWL-TW } \\
\text { (opening left) }\end{array}$ & 73.1 & 737.5 & 0.210 \\
\hline \multirow{4}{*}{$\begin{array}{l}\text { Lee et } \\
\text { al. } \\
(2006)\end{array}$} & \multirow{2}{*}{ OW } & O50W1C1.2 & 53.0 & 309.0 & 0.121 \\
\hline & & O90W1C1.2 & 95.1 & 470.9 & 0.103 \\
\hline & \multirow{2}{*}{ TW4 } & T50W1C1.2 & 50.3 & 706.3 & 0.293 \\
\hline & & T70W1C1.2 & 74.1 & 953.5 & 0.268 \\
\hline \multirow{7}{*}{$\begin{array}{l}\text { Doh et } \\
\text { al. } \\
\text { (2008) }\end{array}$} & \multirow{7}{*}{ TW3 } & TSHO & 80.4 & 809.3 & 0.210 \\
\hline & & TSN0 & 50.1 & 502.2 & 0.209 \\
\hline & & TSHC & 80.4 & 715.2 & 0.185 \\
\hline & & TSHL & 80.4 & 668.1 & 0.173 \\
\hline & & TSNR & 50.1 & 421.1 & 0.175 \\
\hline & & TSNC & 50.1 & 353.2 & 0.147 \\
\hline & & TSNL & 50.1 & 257.5 & 0.107 \\
\hline \multirow{6}{*}{ 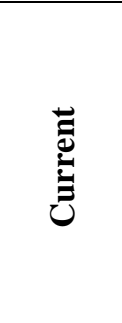 } & \multirow{6}{*}{ TW3 } & TSHC375 & 78.5 & 323.4 & 0.090 \\
\hline & & TSHC450 & 78.5 & 267.5 & 0.074 \\
\hline & & TSHC525 & 78.5 & 210.7 & 0.059 \\
\hline & & TSHR300 & 78.5 & 147.0 & 0.039 \\
\hline & & TSHL300 & 78.5 & 126.6 & 0.034 \\
\hline & & TSHB600 & 78.5 & 267.5 & 0.071 \\
\hline
\end{tabular}

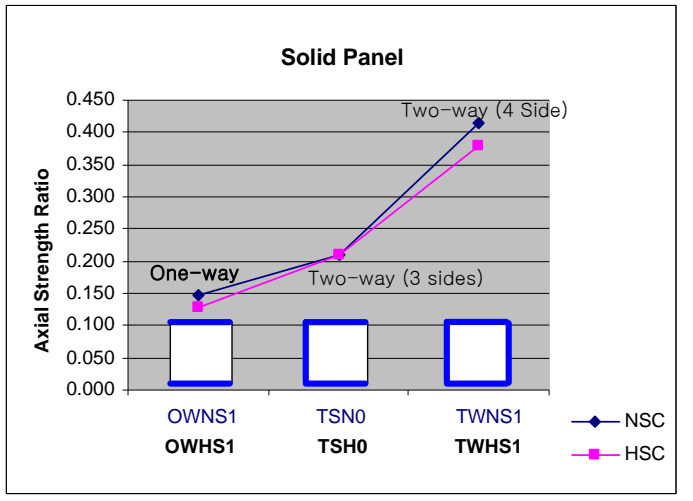

Figure 11. Axial strength ratios vs support conditions (Solid walls)

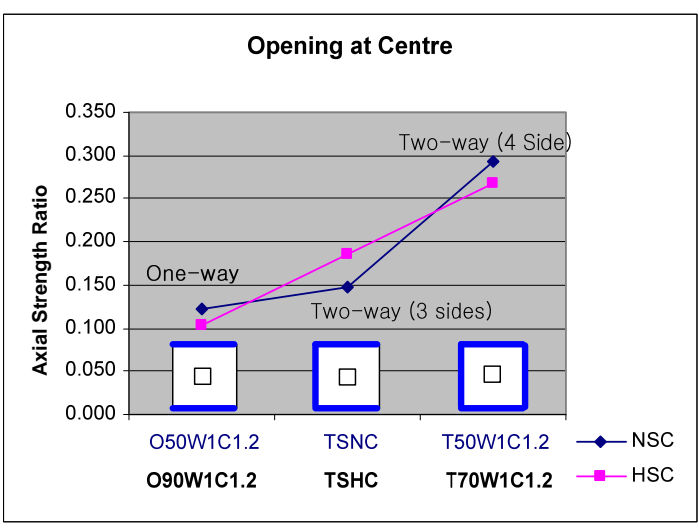

Figure 12. Axial strength ratios vs support conditions (Walls with one opening)

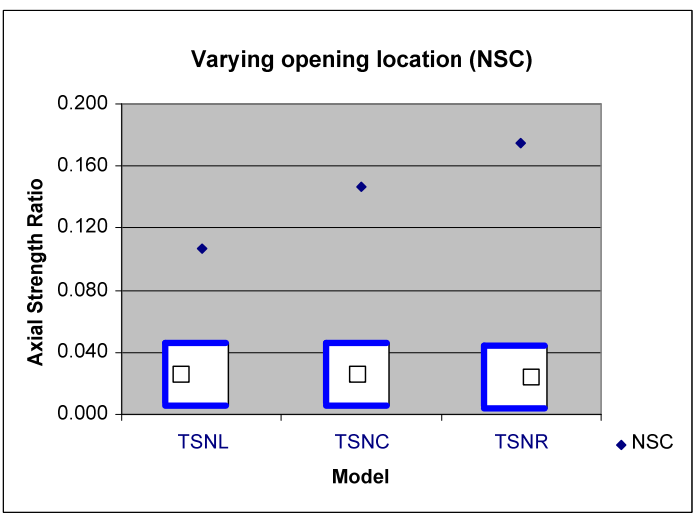

Figure 13. Axial strength ratios vs Opening location (TW3)

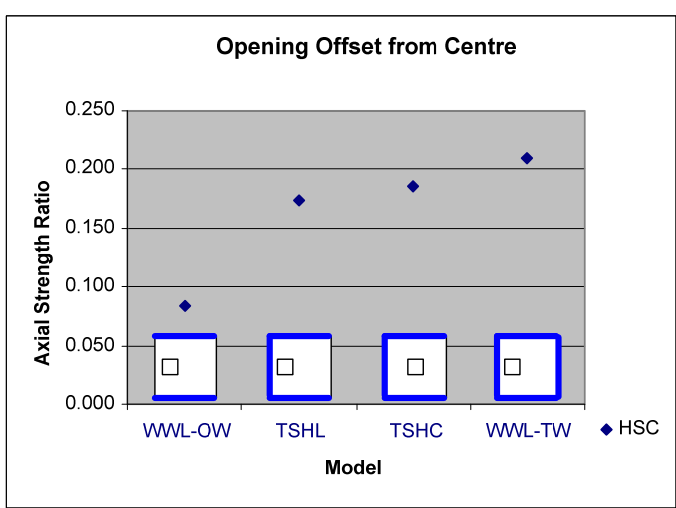

Figure 14. Axial strength ratios vs opening locations 


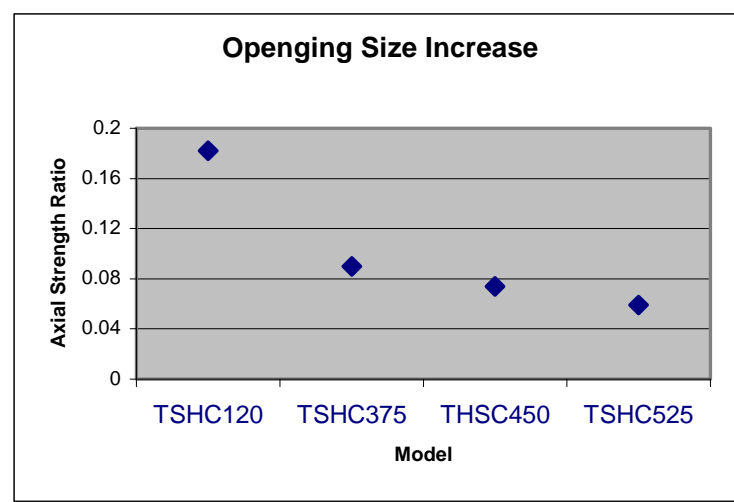

Figure 15. Axial strength ratios vs Opening sizes (TW3)

\section{CONCLUSIONS}

The simplified wall design equation in AS36002009 has been updated to allow for side restraints. As such the load capacity for walls supported on two, three or four sides is accounted for. There is a lack of available data on the behaviour of two-way walls with three sides supported. This paper has reported on recent work on walls supported on three sides with and without openings, and subjected to eccentric axial loadings.

The study found that side supports affects the cracking behaviour and ultimate strength of wall panels when compared to similar walls supported on two or four sides. Also various wall openings and their location affects the overall behaviour. The reported work is significant and provides information for further enhancement and verification of the code equation, particularly for walls supported on three sides and walls with openings.

\section{REFERENCES}

ACI318-2008, Building Code Requirements for Reinforced Concrete, American Concrete Institute Detroit.

AS3600-2009, Concrete Structures, Standards Australia, Sydney, Australia, 2009.

AS3600-2001, Concrete Structures, Standards Australia, Sydney, Australia 2001.

BS8110-1997, Structural Use of Concrete, Part 1 - Code of practice for Design and Construction, British Standards Institution, London, 1997.

Doh, J.H. (2002), Experimental and theoretical studies of normal and high strength concrete wall panels, $P h D$ Thesis, Griffith University, Gold Coast, Australia 2002.

Doh, J.H. and Fragomeni, S. (2005), "Evaluation of experimental work on concrete walls in one and two-way action”, Australian Journal of Structural Engineering 6(1): 37-52

Doh, J.H. and Fragomeni, S. (2006), "Ultimate Load Formula for Reinforced Concrete Wall Panels with Openings”, Advances in Structural Engineering 9(1): 103-115

Doh, J.H., Fragomeni, S., Loo, Y.C., and Lee D. J (2006), "Design Formula For Walls With Openings", The Pisidhi Karasudhi Symposium, Bangkok, Thailand, 3-5 Aug. 2006, pp.21-26
Doh, J.H., Lee, D.J., Guan, H., and Loo, Y.C., (2008), “Concrete Wall with Various Support Conditions" The 4th International Conference on Advances in Structural Engineering and Mechanics(ASEM'08), CD ROM Proceeding, Jeju, Korea, May 26-28, 2008, pp. 967-975

Fragomeni, S. (1995), Design of normal and high strength reinforced concrete walls, $\mathrm{PhD}$ Thesis, University of Melbourne, Australia 1995.

Fragomeni, S. and Mendis, P.A. 1999. Applicability of current ACI318 Wall Design Formula for High Strength Concrete Walls, Advances in Structural Engineering - International Journal, 2 (2): 103 - 108.

Kripanarayanan, K. M. (1977), Interesting Aspect of the Empirical Wall Design Equation, ACI Structural Journal, Vol. 74, No. 5, May 1977, pp.204-207.

Lee, D.J. (2008), “Experimental and Theoretical study of Normal and high strength concrete wall panels with openings, PhD Thesis, Griffith University, Australia

Lee, D. J., Guan, H., Doh, J. H. and Fragomeni, S.(2006), “Finite element analysis of reinforced concrete walls with openings in one- and two-way action”, Proceedings of the 19th Biennial Conference on the Mechanics of Structures and Materials (ACMSM 19), Christchurch, New Zealand, 29 November-1 December, pp. 681-686

Oberlender, G.D. 1973, Strength investigation of reinforced concrete load bearing wall panels, Ph.D thesis, University of Texas, Arlington.

Pillai, S.U. and Parthasarathy, C.V. 1977. Ultimate Strength and Design of Concrete Walls, Building and Environment, London, 12: 25-29.

Saheb, S. M., \& Desayi, P. 1989. Ultimate Strength of RC Wall Panels in One-Way In-Plane Action, Journal of Structural Engineering, 115(10): 2617 - 2617.

Saheb, S. M., \& Desayi, P. 1990. Ultimate Strength of R.C. Wall Panels in Two-way in-plane action, Journal of Structural Engineering, ASCE, 116(5): 1384-1402.

Saheb, S.M. 1985. Strength and Behaviour of Reinforced Concrete Wall Panels. PhD Thesis, Indian Institute of Science.

Sanjayan, J.G. and Maheswaran. T. 1999. Load Capacity of Slender High-Strength Concrete Walls with Side Supports, ACI Structural journal, 96(4): 571-576.

Seddon, A.E. 1956. The strength of concrete walls under axial and eccentric loads, Symposium on Strength of Concrete Structures, Cement and Concrete Association, May, London.

Swartz, S. E., Rosebraugh, V. H.\& Berman, M. Y. 1974. Buckling Test of Rectangular Concrete Panels. ACI Journal, 71: 33-39.

Zielinski, Z.A., Troitski, M.S. and Christodoulou, H. 1982. Full-scale Bearing Strength Investigation of Thin WallRibbed Reinforced Concrete Panels, ACI Journal, 79: 313321.

Zielinski, Z.A., Troitski, M.S. and El-Chakieh, E. 1983. Bearing Capacity Tests on Precast Concrete Thin-Wall Ribbed Panels, Prestressed Concrete Institute Journal, Chicago, 28(3): 89-103 